\title{
Latero-lateral femoro-femoral arteriovenous fistula. A new surgical approach for hemodialysis patients with no vascular access ${ }^{1}$
}

\author{
Fístula artériovenosa fêmoro-femoral látero-lateral. Uma nova abordagem para hemodiálise \\ de pacientes sem opção de acesso vascular
}

\begin{abstract}
Jesualdo Cerri ${ }^{I}$, Eduardo Ramacciotti", Marise Gomes ${ }^{I I}$, Wagner Tedeschi Filho ${ }^{\text {III }}$, Carlos Eli Piccinato ${ }^{\mathrm{IV}}$
${ }^{1}$ Research performed at Division of Vascular and Endovascular, Department of Surgery and Anatomy, University Hospital, School of Medicine of Ribeirao Preto (FMRP), Sao Paulo University (USP), Brazil.

I PhD, Associate Professor, Division of Vascular and Endovascular Surgery, Ribeirao Preto School of Medicine, Department of Surgery and Anatomy, University Hospital, FMRP-USP, Ribeirao Preto-SP, Brazil. Conception and design. Responsible surgical procedure.

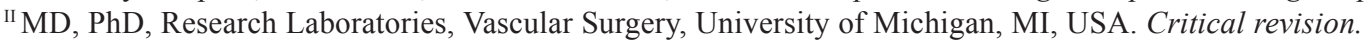

${ }^{\mathrm{III}} \mathrm{MD}$, Master degree, Division of Vascular and Endovascular Surgery, Ribeirao Preto School of Medicine, Department of Surgery and Anatomy, University Hospital, FMRP-USP, Ribeirao Preto-SP, Brazil. Data acquisition and iconography.

${ }^{\text {IV }} \mathrm{MD}$, PhD, Chairman and Head of the Division of Vascular and Endovascular Surgery, Department of Surgery and Anatomy, University Hospital, FMRP-USP, Ribeirao Preto-SP, Brazil. Main author. Supervised all phases of the study. Provided guidelines for the surgical interventions.
\end{abstract}

\begin{abstract}
Purpose: A new surgical approach for vascular access for hemodialysis using a latero-lateral arteriovenous fistula (AVF) in the thigh between the femoral artery (FA) and superficial femoral vein (SFV) transposed to the subcutaneous layer in patients with no other access options is described. Methods: Ten patients (mean age: 37,9 years) for whom all possible sites for execution of any other procedure had been exhausted, underwent latero-lateral AVF close to the adductor channel between the FA and the SFV. The FSV was released and sectioned $2 \mathrm{~cm}$ from its confluence with the deep femoral vein and transposed in the subcutaneous tissue with extensions using saphenous vein or prosthetic material (PTFE) when needed. Follow -up included patency, flow evaluation and complications. Results: Postoperative follow-up ranged from 3 to 96 months, with a mean of 38 months. The AVFs presented a flow of more than 350 $\mathrm{ml} / \mathrm{min}$ and the AVFs remained patent for a mean period of 38 months. There were three failures of the procedures at 3,5 and 7 months during postoperative follow-up due to graft infection and thrombosis (a case), anaphylactic shock and thrombosis (a case) and calf pain during dialysis (a case). Two patients developed slight inferior limb edema. Conclusion: The new surgical approach for access for hemodialysis represents a feasible procedure, with acceptable patency rates in exceptional cases where no other access option is available.
\end{abstract}

Key words: Arteriovenous Fistula. Femoral Vein. Femoral Artery. Renal Dialysis.

\section{RESUMO}

Objetivo: Nova abordagem para acesso vascular para hemodiálise usando fistula artério-venosa (FAV) látero-lateral na coxa entre a artéria femoral (AF) e a veia femoral superficial (VFS) transposta no subcutâneo em pacientes sem opção de acesso. Métodos: Dez pacientes (idade média 37,9 anos), cuja possibilidade de acesso havia sido exaurido, foram submetidos a FAV látero-lateral na coxa entre a AF e a VFS.Esta veia foi liberada e seccionada $2 \mathrm{~cm}$ de sua confluência com a veia femoral profunda e transposta no plano superficial com extensão usando a veia safena ou material protético (PTFE) quando necessário.O seguimento incluíu a perviedade , fluxo e complicações. Resultados: O seguimento pós-operatório foi de 3 a 96 meses (média 38). A FAV apresentou fluxo mínimo de $350 \mathrm{ml} / \mathrm{min}$ e permaneceu pérvia no período médio de 38 meses. Houve 3 falências aos 3, 5, e 7 meses pós-operatórios por infecção de prótese e trombose da FAV (um caso), choque anafilático e trombose (um caso) e dor na panturrilha na hemodiálise (um caso). Dois pacientes desenvolveram discreto edema de membro inferior. Conclusão: A nova abordagem para acesso vascular para hemodiálise representa um procedimento factível, com aceitável perviedade em casos excepcionais onde nenhum outro acesso é disponível.

Descritores: Fístula Arteriovenosa. Veia Femoral. Artéria Femoral. Diálise Renal. 


\section{Introduction}

Treatment quality with periodic hemodialysis (HD) is widely dependent on a good vascular access. The most commonly used access for HD, an arteriovenous fistula (AVF) was described in 1966 by Brescia and Cimino ${ }^{1}$. However, due to repeated punctures and new dissections, thrombophebitis and occlusions are frequent complications leading to the vascular access loss. New means of vascular access are required while those patients remain in line waiting for kidney transplantation ${ }^{2}$. Moreover, the alternative method involving the use of Continuous Ambulatory Peritoneal Dialysis (CAPD) ${ }^{3}$ is not available for a large number of patients; this procedure requires thorough sterile management, with peritonitis as a major complication.

A vascular access using the superficial femoral vein (SFV) has been previously reported ${ }^{4-7}$ with contradictory results. Some patients developed severe chronic venous insufficiency, others display steal syndrome and even amputations are reported ${ }^{8}$.

In a recent meta-analysis, Antoniou et al. ${ }^{9}$ compared the upper thigh prosthetic, the mid-thigh prosthetic and the femoral vein transposition arteriovenous as lower-extremity vascular access. They report femoral vein transposition having better patency rates than femoral grafts, with a 12 months mean primary patency rates of $48 \%, 43 \%$ and $83 \%$, respectively. Access loss as a result of infection was more common in upper thigh and mid-thigh grafts than femoral vein transposition arteriovenous access $(18.40 \%, 18.33 \%$ vs. $1.61 \% ; \mathrm{p}<0.05)$.

We present our experience with a possible alternative vascular access procedure namely the latero-lateral femorofemoral arteriovenous fistula with the superficialization of the superficial femoral vein (SFV). In this new approach, the distal femoral artery (FA) is anastomosed to the SFV avoiding popliteal vein (PV) ligation, effectively preserving the deep venous flow from the lower limb.

\section{Methods}

A total of 10 patients underwent this vascular access procedure at University Hospital, Ribeirao Preto-School of Medicine, University of Sao Paulo. Seven were females and three males patients. The details of the demographic features of these patients are given in Table 1 .

TABLE 1 - General characteristics of the patients (patient number, age, gender, disease, number of complications/patient, time of pre operative of dialysis, duration of the procedure, extension)

\begin{tabular}{|c|c|c|c|c|c|c|c|}
\hline N. & $\begin{array}{l}\text { Age } \\
\text { (yrs) }\end{array}$ & Gender & Disease & $\begin{array}{l}\text { Number of } \\
\text { complications } \\
\text { /patient }\end{array}$ & $\begin{array}{l}\text { Time of pre } \\
\text { op dialysis } \\
\text { (months) }\end{array}$ & $\begin{array}{l}\text { Duration of } \\
\text { the } \\
\text { procedure } \\
\text { (min) }\end{array}$ & Extension \\
\hline 1 & 35 & $\mathrm{~F}$ & $\begin{array}{c}\text { intersticial } \\
\text { nephritis }\end{array}$ & 11 & 7 & 165 & PTFE* \\
\hline 2 & 36 & M & pielonephritis & 9 & 15 & 180 & $\begin{array}{l}\text { GSF** } \\
\text { stump }\end{array}$ \\
\hline 3 & 41 & $\mathrm{~F}$ & unknown & 16 & 132 & 140 & GSV \\
\hline 4 & 40 & $\mathrm{~F}$ & pielonephritis & 9 & 40 & 165 & $\begin{array}{l}\text { bifurcated } \\
\text { SFV }^{+}\end{array}$ \\
\hline 5 & 35 & $\mathrm{~F}$ & diabetes & 12 & 24 & 130 & PTFE \\
\hline 6 & 28 & $\mathrm{~F}$ & pielonephritis & 10 & 84 & 155 & PTFE \\
\hline 7 & 38 & $\mathrm{~F}$ & pielonephritis & 15 & 36 & 170 & $\begin{array}{c}\text { bifurcated } \\
\text { SFV }\end{array}$ \\
\hline 8 & 35 & $\mathrm{~F}$ & $\begin{array}{l}\text { glomerulo } \\
\text { nephritis }\end{array}$ & 7 & 96 & 150 & GSV \\
\hline 9 & 61 & M & pielonephritis & 7 & 25 & 275 & GSF \\
\hline 10 & 30 & M & pielonephritis & 10 & 132 & 180 & GSF \\
\hline Mean & 37,9 & & & 10,6 & 59,1 & 171 & \\
\hline $\mathrm{SD}^{\circ}$ & 9,05 & & & 3,03 & 47,80 & 39,99 & \\
\hline $\begin{array}{l}\text { * politetr } \\
* \text { greater } \\
+ \text { superfic } \\
\text { standarc }\end{array}$ & $\begin{array}{l}\text { etilene } \\
\text { nous ve } \\
\text { noral v } \\
\text { ation }\end{array}$ & & & & & & \\
\hline
\end{tabular}


TABLE 2 - General characteristics of the patients (patient number, diameters of artery and vein, superficial femoral vein [SFV] length, beginning of dialysis post operative, complications post operative, follow up)

\begin{tabular}{|c|c|c|c|c|c|c|}
\hline \multirow[t]{2}{*}{ N. } & \multicolumn{2}{|c|}{ Diameters (cm) } & \multirow[t]{2}{*}{$\begin{array}{l}\text { SFV lenght } \\
\text { (cm) }\end{array}$} & \multirow[t]{2}{*}{$\begin{array}{c}\text { Beggining of dialysis } \\
\text { postop } \\
\text { (days) }\end{array}$} & \multirow[t]{2}{*}{$\begin{array}{l}\text { Complications } \\
\text { post operative }\end{array}$} & \multirow[t]{2}{*}{$\begin{array}{c}\text { Follow } \\
\text { Up } \\
\text { (months) }\end{array}$} \\
\hline & Artery & Vein & & & & \\
\hline 1 & 0,7 & 0,8 & 13,6 & 45 & skin necrosis & 72 \\
\hline 2 & 0,6 & 0,9 & 12,5 & 30 & & 96 \\
\hline 3 & 0,8 & 0,85 & 14,5 & 30 & $\begin{array}{l}\text { closure of the } \\
\text { AVF* }\end{array}$ & 3 \\
\hline 4 & 0,65 & 1,0 & 13,6 & 30 & AVF thrombosis & 5 \\
\hline 5 & 0,7 & 0,9 & 12,8 & 45 & $\begin{array}{l}\text { Infection of the } \\
\text { graft and } \\
\text { thrombosis }\end{array}$ & 7 \\
\hline 6 & 0,7 & 0,85 & 13,7 & 30 & & 31 \\
\hline 7 & 0,76 & 0,95 & 16,0 & 30 & & 67 \\
\hline 8 & 0,65 & 1,0 & 15,7 & 30 & & 14 \\
\hline 9 & 0,8 & 0,85 & 15 & 39 & - & 82 \\
\hline 10 & 0,7 & 0,80 & 14 & 40 & - & 3 \\
\hline Mean & $\mathbf{0 , 7 0}$ & 0,89 & 14,14 & 34,9 & & 38 \\
\hline SD $^{\bullet}$ & 0,07 & 0,07 & 1,16 & 6,59 & & 37,15 \\
\hline
\end{tabular}

* arterio venous fistula

- standard deviation

The basic criterion for inclusion in the exception group was the presence of permeable arterial and venous systems, absence of chronic arterial obstruction, and chronic venous insufficiency (CVI).

Institutional review board (Research Ethics Committee Hospital of the Faculty of Medicine of Ribeirao Preto-University of Sao Paulo) approval was obtained. All patients signed informed consent forms prior to any procedure.

\section{Surgical technique}

The procedures were carried out with continuous epidural anesthesia. A latero-lateral AVF between femoral artery (FA) and the SFV was performed close to the adductor channel. The length of the arteriotomy was $\pm 1 \mathrm{~cm}$. The FSV was released and sectioned $2 \mathrm{~cm}$ from its confluence with the deep femoral vein and transposed to the superficial plane in the subcutaneous tissue. The continuity of the FSV was reestablished in 3 patients by interposing a PTFE segment measuring $4 \mathrm{~cm}$ in length and 8 $\mathrm{mm}$ in diameter between the proximal and distal stumps of the sectioned vein. Separate stitches with polypropylene 6.0 sutures were used. In the remaining cases, the continuity of the vein was reestablished using the greater saphenous vein in 3 patients. In 2 patients, the procedure involved resection of a segment of the bifid FSV, which was interposed between the proximal and distal stumps of the sectioned vein, with polypropylene 6.0 sutures using an automatic needle (Figures 1, 2 and 3).

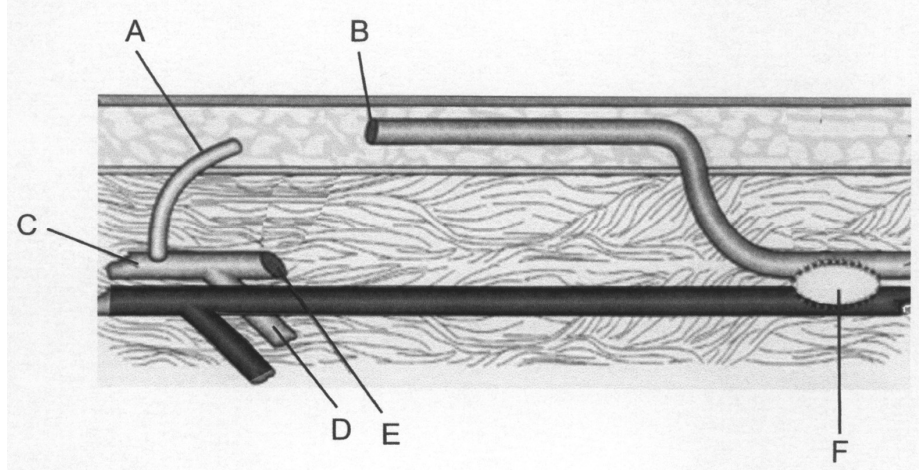

FIGURE 1 - Superficial femoral vein superficialization. A. Greater saphenous vein. B. SFV in the subcutaneous layer. C. Femoral vein. D. Deep femoral vein. E. SFV stump. F. Femoral artery - SFV anastomosis.

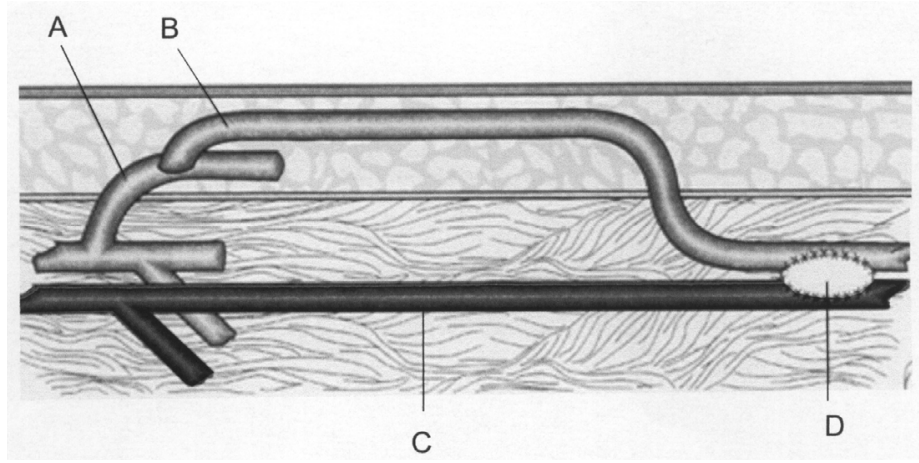

FIGURE 2 - Superficial femoral vein extension. A. Greater saphenous vein. B. SFV in the subcutaneous layer. C. Femoral artery. D. Femoral artery - SFV anastomosis. 


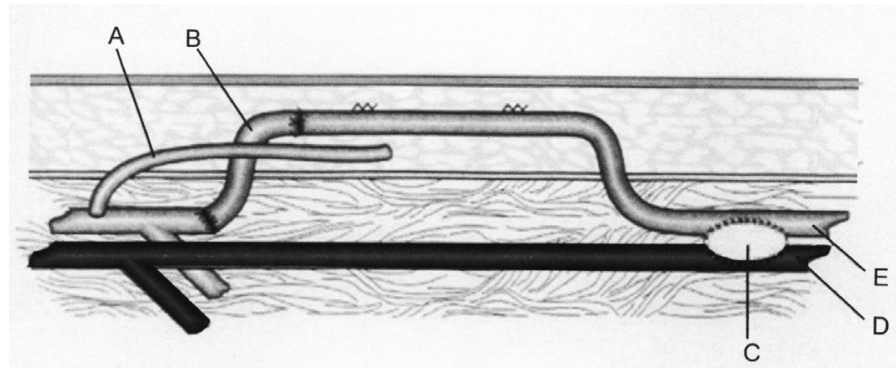

FIGURE 3 - Superficial femoral vein extension. A. Greater saphenous vein. B. PTFE $8 \mathrm{~mm}$ interposition graft. C. Femoral artery - SFV anastomosis. D. Popliteal artery. E. Patent popliteal vein.

\section{Follow-up}

Previous access failure causes were analyzed. Surgical procedure duration, vessels diameter and length measurements, blood loss and anastomosis site were also recorded. Post-operative follow - up included AVF patency, venous flow (measured on HD) and complications such as congestive heart failure, steal syndrome, venous hypertension, occlusions, thrombosis, wound healing and infection were also evaluated.

\section{Results}

Thrombosis of the fistula, infection of the prosthesis and Hickman catheters, veins of small diameters, thickened arteries, and peritonitis were the most common events responsible for the loss of vascular access, with a mean of 10,1 events/patient. Mean time of dialysis during the preoperative period was 66.1 months. The procedures were carried out with no intra- operative complications and lasted on average $2 \mathrm{~h}$ and $56 \mathrm{~min}$. Anastomosis sites were all involving distal FA and SFV. Blood loss was minimum, no patient required blood transfusions. Mean arterial diameter was $0.71 \mathrm{~cm}$. SFV mean diameter was $0.89 \mathrm{~cm}$, with a mean length of $14.53 \mathrm{~cm}$.

All AVFs were patent at the end of the procedure. Mean time from the beginning of dialysis was 35.6 days. The AVFs presented a flow of more than $350 \mathrm{ml} / \mathrm{min}$. Postoperative follow-up ranged from 3 to 96 months, with a mean of 38 months. Two complications from the surgical wound occurred during the postoperative period, with partial necrosis of the skin and of subcutaneous cellular tissue that healed with the application of daily dressings. There were three failures of vascular access at 3, 5 and 7 months during postoperative follow-up due to a case of infection of the PTFE prosthesis which had to be removed, one case of AVF thrombosis resulting from anaphylactic shock with prolonged hypotension, and one case of a patient presenting calf pain (with no signal of ischemia) during the dialysis sections who requested interruption of the fistula. Two patients developed slight inferior limb edema, which was corrected with an elastic stocking. One patient presented cardiac insufficiency not related to the fistula. No steal syndrome was observed. The AVFs remained patent in an overall time of 38 months.

\section{Discussion}

The best results with AVF for HD are still achieved with the classic Bescia and Cimino AVF, a distal anastomosis of the radial artery with the cephalic vein. The patency rates are around 80 to $87 \%$ in a follow-up of 36 months ${ }^{10-12}$.

When upper limbs are no longer available for vascular access, lower limbs (particularly thighs) are an option.

$\mathrm{SFV}$ is an excellent vessel to use in $\mathrm{HD}^{13}$. The diameter ranges from 6 to $8 \mathrm{~mm}$ for an adult, and the wall is thick. This vein has been used extensively as a conduit for aortic reconstructions, venous reconstructions, infra-inguinal revascularizations and as an arteriovenous fistula for HD with good long term results ${ }^{13}$. Jackson and colleagues ${ }^{6}$ reported that the superficial femoral vein is an ideal material for vascular access in the lower extremities. However, complications are frequent including thromboses, cardiac failure, symptomatic distal leg ischemia (steal syndrome), aneurysm, edema of the limb and infection ${ }^{14,15}$. Despite of having reported low incidence of CVI, steal syndrome is a major concern as well. Grandman and collaborators ${ }^{5,16}$ reported 8 cases of steal syndrome in a series of 25 patients, including a case of amputation due to compartmental syndrome.

We constructed a different SFV access for two reasons. Primarily, avoiding popliteal ligature would prevent CVI. Secondly, a distal anastomosis with a small AV diameter would prevent steal syndrome, as previously reported by Holman ${ }^{17}$, Storey ${ }^{18}$ and Ramacciotti ${ }^{19}$.

In our series, no steal syndrome was observed. Only two patients developed edema. Infection occurred in only one subject, in the 7 month follow-up of a patient who had a PTFE composite graft. Infections of PTFE are reported as 4 fold higher than native vessels ${ }^{20}$. Three patients received PTFE extensions, and 7 had a venous interposition (either GSF of duplicated SFV segment), justifying this low infection incidence.

The flow observed in the HD was $350 \mathrm{ml} / \mathrm{min}$; no patient presented decreased flow nor needed ancillary maneuvers to increase dialysis flow.

Failures occurred in 3 patients in the follow-up. However, in two cases no relation with the technique was found; one patient experienced anaphylactic shock and another was submitted to a surgical interruption of the vascular access due to personal reasons. Considering the mean duration of patency reported of 38 months, it exceeds the results obtained by other investigators using autogenous fistulae of the upper limbs.

\section{Conclusion}

This new procedure, keeping the deep venous flow of the inferior limb, is an alternative for patients who are no longer candidates to conventional vascular access. Results of this procedure are satisfactory with good flow rates, and can be used as alternative vascular access for exceptional cases. 


\section{References}

1. Brescia MJ, Cimino JE, Appel K, Hurwich BJ. Chronic hemodialysis using venipuncture and a surgically created arteriovenous fistula. N Engl J Med. 1966;275:1089-2.

2. Budruddin M, Mohsin N, Amitabh J, Ehab M, Pramod K, Abbas P, Khalil M, Al-Lawati S. Femoral vein tunneled catheters as a last resort to vascular access: report of five -cases and review of literature. Ren Fail. 2009;31:320-2.

3. Boen ST. The clinical importance of peritoneal dialysis. Ned Tijdschr Geneeskd. 1962;106:353-6.

4. Bolton WD, Cull DL, Taylor SM, Carsten CG 3rd, Snyder BA, Sullivan TM, Youkey JR, Langan EM 3rd, Gray BH. The use of cryopreserved femoral vein grafts for hemodialysis access in patients at high risk for infection: a word of caution. J Vasc Surg. 2002;36:464-8.

5. Gradman WS, Cohen W, Haji-Aghaii M. Arteriovenous fistula construction in the thigh with transposed superficial femoral vein: our initial experience. J Vasc Surg. 2001;33:968-75.

6. Jackson MR. The superficial femoral-popliteal vein transposition fistula: description of a new vascular access procedure. J Am Coll Surg. 2000;191:581-4.

7. Kapala A, Szczesny W, Stankiewicz W, Hryncewicz W. Vascular access for chronic dialysis using the superficial femoral vein. J Vasc Access. 2003;4:150-3.

8. Huber TS, Ozaki CK, Flynn TC, Ross EA, Seeger JM. Use of superficial femoral vein for hemodialysis arteriovenous access. J Vasc Surg. 2000;31:1038-41.

9. Antoniou GA, Lazarides MK, Georgiadis GS, Sfyroeras GS, Nikolopoulos ES, Giannoukas AD. Lower-extremity arteriovenous access for haemodialysis: a systematic review. Eur J Vasc Endovasc Surg. 2009;38:365-72.

10. Kinnaert P, Vereerstraeten P, Toussaint C, Van Geertruyden J. Nine years experience with internal arteriovenous fistulas for haemodialysis: a study of some factors influencing the results. Br J Surg. 1977;64:242-6.
11. Reilly DT, Wood RF, Bell PR. Prospective study of dialysis fistulas: problem patients and their treatment. Br J Surg. 1982;69:549-53.

12. Zibari GB, Rohr MS, Landreneau MD, Bridges RM, DeVault GA, Petty FH, Costley KJ, Brown ST, McDonald J. Complications from permanent hemodialysis vascular access. Surgery. 1988;104:681-6.

13. Moncef G. Arterio-arterial graft interposition and superficial femoral vein transposition: an unusual vascular access. Saudi J Kidney Dis Transpl. 2005;16:171-5.

14. Fee HJ Jr., Golding AL. Lower extremity ischemia after femoral arteriovenous bovine shunts. Ann Surg. 1976;183:42-5.

15. Fee HJ, Levisman J, Doud RB, Golding AL. High-output congestive failure from femoral arteriovenous shunts for vascular access. Ann Surg. 1976;183:321-3.

16. Gradman WS, Laub J, Cohen W. Femoral vein transposition for arteriovenous hemodialysis access: improved patient selection and intraoperative measures reduce postoperative ischemia. J Vasc Surg. 2005;41:279-84.

17. Holman E, Taylor G. Problems in the dynamics of blood flow. II. Pressure relations at site of an arteriovenous fistula. Angiology. 1952;3:415-30.

18. Storey BG, George CR, Stewart JH, Tiller DJ, May J, Sheil AG. Embolic and ischemic complications after anastomosis of radial artery to cephalic vein. Surgery. 1969;66:325-7.

19. Ramacciotti E, Galego SJ, Gomes M, Goldenberg S, De Oliveira Gomes P, Pinto Ortiz J. Fistula size and hemodynamics: an experimental model in canine femoral arteriovenous fistulas. J Vasc Access. 2007;8:33-43.

20. Minga TE, Flanagan KH, Allon M. Clinical consequences of infected arteriovenous grafts in hemodialysis patients. Am J Kidney Dis. 2001;38:975-8.

\section{Correspondence:}

Carlos Eli Piccinato

Divisão de Cirurgia Vascular e Endovascular

Depto. Cirurgia e Anatomia

Faculdade de Medicina de Ribeirão Preto

Campus Universitário Monte Alegre

14048-900 Ribeirão Preto - SP Brasil

Phone: (55 16)3602-2593

Fax: (55 16)3633-0836

cepiccin@fmrp.usp.br

cepiccin@enrp.usp.br

Received: July 14, 2010

Review: September 16, 2010

Accepted: October 19, 2010 